\title{
Conversations with the Recent Past
}

The following short articles were based on interviews conducted by Luther College faculty and students with elderly residents of the Decorah, Iowa area. Luis Torres, a member of the History Department, explains, in the introduction below, how the "interviews project" got started.

THE WORK which resulted in these articles was done during the January term of 1975 at Luther in a course entitled "Winneshiek County Foxfire." I wanted my students to take part in an endeavor similar to the now famous Foxfire Project in Rabun Gap, Georgia. Eliot Wigginton, originator of Foxfire magazine (from which three Foxfire books were compiled) and a high school English teacher, put his students at work interviewing the older residents of the area. Wigginton had hit upon a novel way of getting young people interested in the problems of communication and language. At the same time, he had discovered an ideal solution to the problem of collecting and preserving local history, traditions and lore through the practice of oral history at the grassroots level, something which had previously been sadly neglected in our country. The project resulted in great benefits for the participating students, for the subjects they interviewed, and for the area they both lived in. No wonder that Wigginton's idea has found so many imitators since the public first became aware of it.

Our Winneshiek County Foxfire started out with only the knowledge that the Rabun Gap project had worked to keep us going. We had no special budget. Our blank tapes and raw film were provided by the college library on the condition that the material collected would be deposited there as part of the Winneshiek County Archives. Casette recorders were borrowed from the instructional media department or were provided by the students themselves. Only two of the original twenty-five students were from northeast Iowa; none of the rest had any special famil- 
iarity with the area. Transportation was volunteered by those who had cars. The two student photographers and the colleague who was helping with the project, Rev. Harley Refsal, used their own cameras.

Under these conditions, it is a wonder that we were able to achieve anything, but the enthusiasm generated by the contacts between the students and the people they interviewed enabled us to overcome the difficulties we encountered. The result was that at the end of January the students were unwilling to see the project come to an end. They petitioned for the establishment of a regular course that would continue the work, I agreed to supervise it, and the Northeast Iowa Oral History Project was the result.

The articles that the students wrote from their interviews have appeared as a regular series in Chips, the weekly student newspaper, and have been picked up by the local Decorah Newspapers. We are still operating on a shoestring, but our project has been endorsed as a State Bicentennial Project by the Iowa American Revolution Bicentennial Commission, which has also helped us with a money grant. A paperback book, Conversations With the Recent Past, containing some of the material we have collected thus far is now available from Luther College. (Price: \$4)

For me as both teacher and historian, there have been untold satisfactions in this work. These can perhaps be best summarized in the comment of one of the student authors represented in this issue when during a tour of the surviving log buildings in the area, we visited one of the oldest farmsteads in Winneshiek County, which now lies abandoned. As we walked away, he said: "You know, two months ago I would have written off that place as just another old house!"

We have just scratched the surface, and that is both encouraging and frustrating. Since Decorah has such a strong Norwegian tradition, we have concentrated on that aspect of the area's heritage. The year 1975 marked the celebration of the sesquicentennial of Norwegian immigration to the United States. With a bit of luck and some time, we hope to get to the Bohemians around Spillville, the Germans in Waukon, the French-Canadians along the Mississippi, the Welsh around Lime Springs, and the many others who lend variety and color to our corner of Iowa. 


\title{
A Norwegian Immigrant Family
}

\author{
by Geraldine Schwarz
}

WHEN KLAUS OLSON STENE LEFT the copper mining area in South Trondelag, Norway, he took his wife and four sons across an ocean and half a continent to find a new life in a new country. The year was 1855 , and the family found a home in northeast Iowa, one of the first three families to settle in the Waterloo Ridge area.

As the sons grew to manhood, they staked out their farms and built their homes on land adjacent to their father's farm, using the same springs and creek for their water supply. One of the brothers, whose farm lay a little way off from the creek, piped water underground in hollowed out logs to water his livestockthe path those logs took can be traced today by seepage along the surface. And today when we stand on the top of Waterloo Ridge and look down at Klaus Olson Stene's farm and the farms that belonged to the four Klauson (Clauson) brothers, we are struck with the feeling that this country was settled and maintained by and for families.

It was the family, intact or in part, that came searching for better land and a better life. When a young family was left motherless, it was generally a sister in Norway who was sent over to take care of father and children. When more help was needed on the farm, it was a cousin from Norway who came to help. When a young mother was left widowed in Norway, it was her husband's brother in the new country who sent for her to be his bride. Norwegian families-like all families everywhere-sticking together, helping each other, creating a country.

The family bond was strong. When Tosten Anderson's father died of cholera in a boxcar carrying immigrants to Chicago, Tosten continued the trip to his cousins' farm and became almost a son of the family, being known as Tosten Kjome. It was not until he married and took another farm that he returned to his family name of Anderson. The family bond was so strong that a grandmother would walk five miles on a foot ravaged by gangrene to be with her daughter and grandchildren; or a young mother could 
count on being attended by a grandmother, aunt or cousin at her child's birth. Children whose mothers were ailing or dead were always taken in by relatives. And when the flu epidemic swept Highland Township in 1918-19, people took care of the families of sick relatives in spite of the fact that they were exposing themselves to the disease. Few of those families escaped death during the epidemic. The family bond was so strong that even today most families in Highland Township can trace their relationship to each other in one way or another. And even though some might say this is inbreeding or an attempt to keep property in the family, it is neither of these. It is simply coping with life in a natural and human way. It is caring and sharing.

The family was a strong unit. Again and again the picture is painted of a father who was the unchallenged head of the family. Styrk Sollien is described by his daughter Martina as "strict, but never mean." The rules he set for the family were followed by every member. Even the distasteful jobs-cleaning out the barns, driving the balky horse, fetching the cattle in bad weather-were completed not so much out of fear of punishment as because the father's orders were followed. The father brought order to the family. His rules for times to eat and to do chores made it possible for the mother's work to run smoothly. His rules for caring for tools made it possible for the others to depend on things being in their right place. He was consistent. He could not be bluffed and he made no idle threats.

The mother was also strong but she could be persuaded. She was often soft-hearted, taking back the promised punishment. When she actually carried out a threatened punishment, such as taking a buggy whip to the boy who threw pebbles down the cistern, it was so unusual that it made a lasting impression on her son. Children from those turn-of-the-century families describe their mothers as meek, quiet, or tender-but always as hard workers who took good care of their families.

Probably this is the picture we see of early families not because this was the only way families behaved but because in families where there were eight or ten children, where farming and all the work it involved were the way of life, successful families behaved this way-their survival depended upon it. Fathers had to give the orders and see that the farm work was carried out or the family would not eat. If the father was to maintain this kind of 
discipline, he could not also be gentle and compassionate-the mother sensed this and filled this need in the family.

The family was the institution which was by far the most influential on the children. Although the one-room school education and the Norwegian Lutheran church services and confirmation were important, the family was the core which backed them up and made them meaningful in the children's lives. In a curious blend of respect and tolerance, parents were able to disagree with the school teacher or pastor and yet insist that their children carry out all directions at school or church. When one teacher wanted to shorten the school year by having school on Saturday, it was evident that one father thought five days of school in a week were enough. But he insisted the children attend Saturday school without complaint. Parents might argue for hours with the pastor around the Sunday dinner table but that had nothing to do with the children studying their confirmation lessons. Because of the family, the whole community was solid. And the family held together.

Even today, brothers and sisters who grew up in those families in Highland Township are extremely close. When a person breaks her leg and needs care, she does not go to a nursing home or hire someone to look after things-a member of the family comes to stay with her. A birthday never goes unnoticed-brothers and sisters, cousins and friends all mark the day with visits or phone calls. When a man dies, even if he has outlived many of his friends, the parking lot around the white country church is full of cars belonging to his cousins, nieces, nephews and neighbors. Even if brothers and sisters disagree with each other's politics or economics or habits, they are still extremely loyal and can be counted on whenever they are needed. Their voices are full of pride when they speak of their parents-and also when they speak of their children; generations of families proud of their relatives!

The feeling of family cohesion did not end with the generation of children who grew up in those turn-of-the-century families. When Klaus Olson Stene's great, great grandson, Mike Kjome, disappeared in Vietnam in 1968, no member of that whole great family rested easily until he was located and released. His brother John left college and joined the Navy in hopes of going to Vietnam to find him. When a broken leg forced John to stay in the States, he joined the effort to keep the cause of the POWs in front of the 
public by traveling across the country and presenting programs in a bus which he had painted with the words "Suppose this POW Were Your Brother!" And when Mike was released, members of his family from all over the country and abroad returned to Decorah to be with him and to rejoice.

This is family cohesion.

$$
\text { \# \# }
$$

\section{Golden Harvest}

\section{by Phil Einspahr}

WILLIAM ASK'S FATHER AND BROTHERS were the owners of one of the first threshing machines in northeast Iowa, which they operated in an area with a radius of five miles around their farm next to the Glenwood stone church. Mr. Ask, presently a contractor, has been a farmer, and once owned a milling business. Much of our conversation centered on the operation of the Asks' threshing rig, and I found him to be an excellent source on the finer details of the process.

In an age of air-conditioned combines and diesel tractors, many people fail to realize the hard work that threshing once entailed. Neighbors helping neighbors took many days, often weeks, to bring in the harvest and store it in granaries. Insects, rust, and crop failures resulted in the elimination of wheat in the area, and hay was threshed for the seed only. Oats, therefore, was the main crop threshed.

In the fall, when the grain had properly ripened, the "golden harvest" was ready to begin. The binder, drawn by three or four horses, cut and tied the grain into bundles and laid the bundles in windrows. They were then shocked, heads together to shed water, and cured for anywhere from two days to about a week.

When threshing machines were scarce, the farmers made four large stacks in the field, drove the rig between them, and began threshing. Around 1910, it became popular to windrow and shock 
Copyright of Annals of Iowa is the property of State of Iowa, by \& through the State Historical Society of Iowa and its content may not be copied or emailed to multiple sites or posted to a listserv without the copyright holder's express written permission. However, users may print, download, or email articles for individual use. 